Tihfani Astuti ${ }^{1}$

Lilia Indriani $^{2}$

\section{THE EFL STUDENTS' PERCEPTIONS IN USING GOOGLE CLASSROOM FOR ENGLISH LEARNING DURING PANDEMIC}

\begin{abstract}
Abstrak
Pembelajaran online membutuhkan media tambahan, seperti website dan aplikasi. Salah satu media yang sering digunakan dalam pembelajaran online adalah Google Classroom. Penelitian ini bertujuan untuk mengeksplorasi persepsi siswa EFL tentang penggunaan Google Classroom di kelas bahasa Inggris. Objek penelitian ini adalah 35 siswa SMK Nusawungu Cilacap. Penelitian ini menggunakan metode kualitatif. Peneliti mengambil data dari angket tentang persepsi siswa terhadap pembelajaran menggunakan Google Classroom melalui google form dan menganalisis secara deskriptif serta mengukur data menggunakan skala likert. Hasil penelitian ini sebagian besar siswa setuju dan menerima Google Classroom sebagai media untuk melakukan pembelajaran online karena manfaatnya.
\end{abstract}

Kata Kunci: EFL, Persepsi, Google Classroom.

\begin{abstract}
Online learning requires additional media, such as websites and applications. One of the media that is often used in online learning is Google Classroom. This research aims to explore the EFL students' perception of the use Google Classroom in English classes. Object of this study is 35 students of Vocational High School of Nusawungu, Cilacap. This study uses a qualitative method. The researcher takes data from a questionnaire on students' perceptions of learning using Google Classroom through google form and analyses descriptively and measuring data using a Likert scale. This research results in most students agree and receive Google Classroom as a media to do online learning because of its benefits.
\end{abstract}

Keywords: EFL students, perception, Google Classroom

\title{
INTRODUCTION
}

Nowadays, technology is developing very fast. Technology can contribute to the learning process, especially during this pandemic. COVID-19 pandemic is the first and biggest health crisis in this era. This pandemic very dangerous because it is easy to spread and deadly. The existence of this virus causes many adverse effects in various fields, including in education. This pandemic made state governments make new policies, namely to implement learning from home. Learning from home or online learning means that students continue to study safely at home to break the chain of Covid-19 transmission and ensure the continuity of education. Other media such as websites or applications are needed to facilitate learning activities to do this type

\footnotetext{
${ }^{1}$ Pendidikan Bahasa Inggris, FKIP, Universitas Tidar tihfaniastuti29@gmail.com

${ }^{2}$ Pendidikan Bahasa Inggris, FKIP, Universitas Tidar indriani@untidar.ac.id
} 
of learning. Learning media applications can be beneficial and improving previous learning outcomes. Koc (2016) states that applying technology-based learning can contribute to teaching and learning in this century. Then, Sakkir (2019) argues that teaching staff and teachers should understand and adopt social media to not be out of date with their students. Students' ideas that are not educational and even lies are very close to social media. In this case, teachers and parents need to choose useful and practical social media in learning, as long as students enjoy them.

One of the media used to do online learning is Google Classroom. Google Classroom is an educational feature, the one that provides is the Google Apps for Education (GAFE). It was released on August 12, 2014. This application allows the creation of classrooms but in cyberspace and a free online service for non-profit schools, even those with a google account. It can work in a unidirectional process because it can serve the teacher's strategies and styles on the one hand and the understanding of student perceptions and effective participation in a wide range of classroom skills. The educational community has accepted this application to promote the e-learning process. It makes students and teachers easy to set up and stay connected, both inside and outside.

Northey et al. (2015) argue that Google classroom is very beneficial, adequate, and it provides newer defiances in continuing education in a distinct way. The benefits are available to anyone with tools and applications (Gmail, Drive, and Docs). The teachers can give materials and tasks in form doc, PPT, or youtube link form through these applications. Like the teachers, the students can also submit their assignments in Gmail, drive, or other formats based on the teachers' rules. Daud (2019) also says that teachers can use it for teaching purposes, such as making important announcements, posting assignments, uploading learning materials, and assessing student work. By using google classroom, teachers can create virtual classes, provide information related to the teaching and learning process, and provide teaching materials in the form of files. Teachers also can exposure to learning materials and videos, give students assignments, make a schedule for collecting duties and others.

Second, according to Janzen (2014), Google Classroom is familiar because of its ease. All of the subjects, including English, can be contained there. Students typed the class code provided by the teacher so that they can join the lesson. Abd Syakur et al. (2020) believe that google classrooms are not complicated and more flexible to use. It makes it ideal for lecturers even with diverse levels of an e-learning experience. Besides that, Northey et al. (2015) argue it is also easy to organize work and save time. It can accommodate all the materials and tasks in each subject, so the teacher can easily manage, collect, and provide feedback because they are not mixed between one subject and another.

Third, it can be accessed from laptops, PCs, and mobiles very easily. Lecturers and students can visit the https://classroom.google.com or download the application through Playstore on Android or the App Store on iOS with the keyword Google Classroom. Google Classroom is flexible; it means that the access can be done anywhere and anytime. Students only need a signal and internet connection to access it well. Northey et al. (2015) also argue it shows that the educational community highly recommends Google Classroom. Finally, Google Classrooms as an online learning platform equip flexibility in scheduling, eliminating travel costs and can reach anyone who has access to it.

This research will focus on students' perceptions that will be applied in the questionnaire to observe this application's effects and efficiency. The researcher must initially know the students' perceptions of social media in the classroom. Alnujaidi (2017) argues that perception is an 
external factor that focuses on one's perspective, understanding, trust, and reaction to an innovation. This study illustrates students' views on using Google Classroom in the language learning process with this theory in mind. There are some studies of the EFL study using Google Classroom. As in some previous studies, Irma and Marundut (2020) survey about students' perceptions of using WhatsApp group and Google classroom-based learning material in English classes. Then, Abeer and Khaleel (2020) conducted a study about the effectiveness of Google classroom among EFL students in Jordan with the result that the students there positively received Google Classroom and it is an effective online platform. The study from Andi (2020) about optimization of online learning method application through Google Classroom also shows that most of the students who are the object of his research satisfied with the use of Google Classroom as an online learning method. Therefore, the researcher conducts a research about how the EFL students' perceptions of using Google classroom in the pandemic.

\section{METHOD}

This research is descriptive research that uses qualitative analysis. Qualitative research understands social phenomenon based on the participant's perspective to increase information into a particular phenomenon, environment, process, or belief. This study aims to analyze the EFL students' perceptions of using Google classroom during online learning in this pandemic. The researcher uses a questionnaire in google form to collect the data. The questionnaire is adapted from Abeer and Khaleel (2020), consisting of 16 items distributed among three domains: usefulness domain, ease of use domain, and accessibility domain. The subject of this study is 35 students from the Vocational High School of Nusawungu. The researcher asks each student to respond based on a 5point Likert scale, namely '5' represents 'strongly agree' 4 points represents 'agree' 3 points represents 'disagree or disagree' 2 points represent 'disagree' and 1 point means strongly disagree. To achieve the goal of this study, the researcher does some procedures:

1. First, the researcher searches for some studies related to this study.

2. The researcher makes a questionnaire in Google form by adapt from the previous researcher.

3. The researcher shares the questionnaire to collect the data.

4. Then, the researcher recapitulates data from questionnaire results.

5. Finally, the researcher presents the perceptions of students in using Google Classroom result in a description.

\section{FINDINGS AND DISCUSSION}

To determine students' perceptions of Google Classroom-based learning materials in English classes, the researchers distribute questionnaires to the students in the google form. The data are analyzed using a Likert Scale indicated by the percentage of questionnaires from 35 students. There are three indicators used in filling out the questionnaire: usefulness items, ease of use items, and access items. The indicator components are compiled to be filled by the students on the appropriateness of the applications. From the questionnaire results, the students agree that the Google Classroom in English classes gives some benefits. The researcher concludes that most students in Vocational High School of Nusawungu show that the six indicators used in filling out the questionnaire lead to good compatibility by applying the platforms sustainably to the students. 
Table 1. The Students' Perception in Using Google Classroom

\begin{tabular}{|c|c|c|c|c|c|c|}
\hline No & Statement & $\begin{array}{l}\text { Choice } \\
5\end{array}$ & $\begin{array}{c}\text { Choice } \\
4\end{array}$ & $\begin{array}{c}\text { Choice } \\
3\end{array}$ & $\begin{array}{l}\text { Choice } \\
2\end{array}$ & $\begin{array}{c}\text { Choice } \\
1\end{array}$ \\
\hline \multicolumn{7}{|c|}{ Usefulness Items } \\
\hline 1 & $\begin{array}{l}\text { I look forward to using Google Classroom } \\
\text { in other classes. }\end{array}$ & $23 \%$ & $60 \%$ & $14 \%$ & & $3 \%$ \\
\hline 2 & I find Google Classroom helpful. & $29 \%$ & $57 \%$ & $9 \%$ & $5 \%$ & \\
\hline 3 & I find Google Classroom useful. & $34 \%$ & $54 \%$ & $9 \%$ & $3 \%$ & \\
\hline 4 & $\begin{array}{l}\text { Google Classroom helps me in improving } \\
\text { my writing skills. }\end{array}$ & $11 \%$ & $66 \%$ & $23 \%$ & & \\
\hline 5 & $\begin{array}{l}\text { Google Classroom helps me in improving } \\
\text { my reading skills. }\end{array}$ & $17 \%$ & $66 \%$ & $14 \%$ & $3 \%$ & \\
\hline 6 & Google Classroom activities are helpful. & $26 \%$ & $63 \%$ & $11 \%$ & & \\
\hline 7 & $\begin{array}{l}\text { I like doing activities through Google } \\
\text { Classroom. }\end{array}$ & $14 \%$ & $66 \%$ & $14 \%$ & $6 \%$ & \\
\hline 8 & $\begin{array}{l}\text { Google Classroom should be used in } \\
\text { higher education. }\end{array}$ & $20 \%$ & $63 \%$ & $14 \%$ & $3 \%$ & \\
\hline 9 & $\begin{array}{l}\text { There is value in using Google Classroom } \\
\text { for teaching and learning purposes. }\end{array}$ & $14 \%$ & $60 \%$ & $26 \%$ & & \\
\hline \multicolumn{7}{|c|}{ Ease of Use Items } \\
\hline 10 & $\begin{array}{l}\text { Using Google Classroom application is } \\
\text { easy. }\end{array}$ & $29 \%$ & $51 \%$ & $20 \%$ & & \\
\hline 11 & $\begin{array}{l}\text { I feel instructions of the activities are } \\
\text { clear. }\end{array}$ & $20 \%$ & $60 \%$ & $20 \%$ & & \\
\hline 12 & $\begin{array}{l}\text { I feel positive when submitting my } \\
\text { assignment through Google Classroom. }\end{array}$ & $32 \%$ & $57 \%$ & $11 \%$ & & \\
\hline \multicolumn{7}{|c|}{ Access Items } \\
\hline 13 & $\begin{array}{l}\text { I respond as quickly as possible to each } \\
\text { assignment or question in Google } \\
\text { Classroom. }\end{array}$ & $23 \%$ & $69 \%$ & $8 \%$ & & \\
\hline 14 & $\begin{array}{l}\text { Google Classroom application is available } \\
\text { on my smartphone. }\end{array}$ & $40 \%$ & $51 \%$ & $9 \%$ & & \\
\hline 15 & $\begin{array}{l}\text { I can login into Google Classroom } \\
\text { anytime anywhere. }\end{array}$ & $40 \%$ & $49 \%$ & $11 \%$ & & \\
\hline 16 & $\begin{array}{l}\text { Using Google Classroom in all courses } \\
\text { that have assignments is better than paper- }\end{array}$ & $17 \%$ & $66 \%$ & $17 \%$ & & \\
\hline
\end{tabular}


based assignment.

Based on the table above, the researcher explains that students can use Google Classroom in online learning, especially in this pandemic. The reasons for using this application because it provides some benefits include:

1. The usefulness in using Google Classroom

Most students agree that Google Classroom gives them many uses that other apps do not have, such as it can be used in other classes, increase students' skills, and the activities are useful. Each item in the context of the questionnaire's usefulness in the questionnaire shows that most of the 35 students agree with the statements contained in the questionnaire. The percentages are $60 \%, 57 \%, 54 \%, 66 \%, 66 \%, 63 \%, 66 \%, 63 \%$, and $60 \%$. Each of these percentages is the highest percentage among the other choices (strongly agree, neutral, disagree, and strongly disagree). The second highest rate is in the strongly agree position. These results indicate a positive response to the use of Google Classroom in the context of usefulness.

2. The ease of use in using Google Classroom.

Most students agree that Google Class is easy to use; an example of simplicity is because the instructions are clear and easy to submit multiple tasks. Each item in the context of the questionnaire's usefulness in the questionnaire shows that most of the 35 students agree with the statements contained in the questionnaire. These percentages are $51 \%, 60 \%$, and $57 \%$. Each of these percentages is the highest percentage among the other choices (strongly agree, neutral, disagree, and strongly disagree). The second highest percentage is choice 5, which means strongly agree. These results show a positive response to the use of Google Classroom in the context of convenience.

3. The access of Google Classroom

The students can access it to do some tasks there. It is available on the smartphone, not only on the laptop. It can also be accessed anytime and anywhere, and easy to access to do the assignment than use paper. Each item in the context of the questionnaire's usefulness in the questionnaire shows that most of the 35 students agree with the statements contained in the questionnaire. The percentages are $69 \%, 51 \%, 49 \%$, and $66 \%$. Each of these percentages is the highest percentage among the other percentages (strongly agree, neutral, disagree, and strongly disagree). The second highest rate is in the same strongly agree position. These results show a positive response to the use of Google Classroom in the context of accessibility.

\section{CONCLUSION}

At this time, education needs to implement the new education system. Technology is important and provides benefits for education. Overall, this study attempts to determine the Vocational High School of Nusawungu students' perception in using Google Classroom. Based on the finding and discussion, there are some data as results of this study. According to the results of the questionnaire, the research concludes that Google Classroom has many benefits for both teachers and students. It can be applied as a media or platform to do online learning, especially in this pandemic. Google Classroom is effective to use, it helps students to be able to learn even if they are far away from the teacher. Most of the students at the Vocational High School of Nusawungu perceive Google Classroom positively in terms of usefulness, ease of use, and accessibility. The highest percentage of the questionnaire is choice ' 4 ', which means agree 
with the questionnaire statement, and the second is choice ' 5 ' which means strongly agree. It means that Google Classroom is an appropriate platform to support learning from home.

\section{REFERENCES}

Putri, A. M. J. (2020). Optimization of Online Learning Method Application through Google Classroom. Journal of English and Development, 4(1), 1-8. https://doi.org/10.31605/eduvelop.v4i1.754

Barus, I. R. R. G. \& Simanjuntak, M. B. (2020). Whatsapp Group and Google ClassroomBased Learning Materials in English Classes: Students' Perceptions (Study Case taken from College of Vocational Studies - IPB University). Scope of English Language Teaching, Literature and Linguistics, 3(1), 2623-2642. https://ejournals.umma.ac.id/index.php/seltics

Koc, D. K. (2016). Students' perceptions of blog use in an undergraduate linguistics course. Journal of Language and Linguistic Studies, 12(1), 9-19. http://www,jlls.org

Likert, R. (1932). A Technique for the Measurement of Attitudes. Archives of Psychology.

Sakkir, G. \& Dollah, S. (2019). Facebook-Based Writing Instructional Material In English Class: Lecturers' Perception. Scope of English Language Teaching, Literature and Linguistics, 2(2), 76-83. https://ejournals.umma.ac.id/index.php/seltics

Agung, A. S. S. N., Surkanti, M. W., \& Quinones, C., A. (2020). Students' Perception of Online Learning during COVID-19 Pandemic: A Case Study on the English Students of STKIP Pamane Talino. Journal of Social Sciences and Humanities, 10(2), 225-235. ojs.pnb.ac.id/index.php/SOSHUM/

Albashtawi, A. H., \& Bataineh, K. B. A. (2020). The Effectiveness of Google Classroom Among EFL Students in Jordan: An Innovative Teaching and Learning Online Platform. International Journal of Emerging Technologies in Learning, 15(11), 78-88. https://doi.org/10.3991/ijet.v15i11.12865

Al-Maroof, R. A. S., \& Al-Emran, M. (2018). Students Acceptance of Google Classroom: An Exploratory Study using the PLS-SEM Approach. International Journal of Emerging Technologies in Learning, 13(6). https://doi.org/10.3991/ijet.v13i06.8275

Heggart, K. R., \&Yoo, J. (2018). Getting the Most from Google classroom: A pedagogical framework for tertiary educators. Australian Journal of Teacher Education, 43(3), 9. https://doi.org/10.14221/ajte.2018v43n3.9

Bahasoa, A., Ayundiani, W., Mukhram, M., \& Rahmat, A. (2020). Effectiveness of Online Learning in Pandemic Covid-19. International Journal of Science, Technology \& Management, 100-106. http://ijstm.inarah.co.id

Famularsih, S. (2020). Students' Experiences in Using Online Learning Applications Due to COVID-19 in English Classroom. Studies in Learning and Tecahing, 1(2), 112-121. 
Cakrawati, L. M. (2017). Students' perceptions on the use of online learning platforms in EFL classroom. English Language Teaching and Technology Journal, 1(1), 22-30. https://doi.org/10.17509/elt\%20tech.v1i1.9428

Purnama, G. (2020). Comparisonof Junior High School Student Mathematics Learning Results Between Students Who Learned Using Whatsapp Group Media with Students Which Learning Using Google Classroom Media in Pandemic Time Covid-19. Journal of Educational Experts, 3(2), 69-73. https://scie-journal.com/index.php/SiLeT

Khairani, A., Daud, A., \& Mahdum. (2020). Students' Acceptance of The Use of Google Classroom As A Platform in Blended Learning. Education Journal, 12(1), 1-16. http://www.journal.staihubbulwathan.id/index.php/alishlah

Azhar, K. A., \& Iqbal, N. (2018). Effectiveness of Google classroom: Teachers' perceptions. Prizren Social Science Journal, 2(2), 52-66.

Daud, A. (2019). Teaching Writing Using Google Apps For Education (GAFE). Indonesian Journal of Economics, Social, and Humanities, 1(1), 17-24. https://doi.org/10.31258/ijesh.1.1.2

Syakur, A., Sugirin, \& Widiarni. (2020). The Effectiveness of English Learning Media through Google Classroom in Higher Education. Britain International of Linguistics, Arts and Education (BIoLAE) Journal, 2(1), 475-483. https://doi.org/10.33258/biolae.v2i1.218

Sholah, H. M. (2020). Teaching and Learning English Using Google Classroom for Indonesian Learners. Jurnal Pusaka, 8(1), 1-12. http://ejournal.alqolam.ac.id

Sanad, H. A. (2016). EFL Students' Perception and Attitudes Toward Facebook as an Educational Learning Tool. International Journal of Humanities and Social Science Invention, 15-25.

Al Maroof, R., Al Emran, M. (2018). Student Acceptance of Google Classroom: An Exploratory Study using PLS-SEMApproach. International Journal of Emerging Technologies in Learning, 13(6), 112-123. https://doi.org/10.3991/ijet.v13i06.8275

Al Emran, M., and Malik, S. I. (2016). The Impact of Google Apps at Work: Higher Educational Perspective. International Journal of Emerging Technologies in Learning, 10(4), 85-88. https://doi.org/10.3991/ijim.v10i4.6181

Harefa, E. B. (2020). Usability Measurement of Google Classroom Applications as E-Learning for Students of Department Building Engineering Education IKIP Gunung Sitoli. Indonesian Education Research, 2(1), 11-14. https://jurnal.unimed.ac.id/2012/index.php/iser

Okmawati, M. (202). The Use of Google Classroom During Pandemic. Journal of English Language Teaching, 9(2), 438-443. http://ejournal.unp.ac.id/index.php/jelt

George, M. L. (2020). Effective Teaching and Examination Strategies for Undergraduate Learning During COVID-19 School Restrictions. Journal of Educational Technology Systems, 49(1), 23-48. http:// journals.sagepub.com/home/ets 
George, M. L. (2018). An effective classroom-based approach for teaching digital logic design to engineering undergraduates. International Journal of Innovative Research and Development, 7(8), 45-53.

Agarwal, S., \& Kaushik, J. S. (2020). Student's Perception of Online Learning during COVID Pandemic. The Indian Journal of Pediatrics, 87(7), 54. https://doi.org/10.1007/s12098020-03327-7

Adnan, M. \& Anwar, K. (2020). Online learning amid the COVID-19 pandemic: Students' perspectives. Journal of Pedagogical Sociology and Psychology, 2(1), 45-51. http://www.doi.org/10.33902/JPSP. 2020261309

Basilaia, G., \& Kvavadze, D. (2020). Transition to online education in schools during a SARSCoV-2 coronavirus (Covid-19) pandemic in Georgia. Pedagogical Research, 5(4), 1-9.

Radha, R., Mahalakshmi, K., Kumar, V. S., \& Saravanakumar A. R. (2020). E-Learning during Lockdown of Covid-19 Pandemic: A Global Perspective. International Journal of Control and Automation, 13(4), 1088-1099.

Abazi, B. L., Kadriu, A., \& Apostolova, T. M. (2018). LMS solution: evidence of Google classroom usage in higher education. Business Systems Research, 9(1), 31-43. https://doi.org/10.2478/bsrj-2018-0003

Kumar, J. M. \& Bervell, B. (2019). Google Classroom for mobile learning in higher education:

Modelling the initial perceptions of students. Education and Information Technologies, l(1), 1-26. https://doi.org/10.1007/s10639-018-09858-z

Jena, P. K. (2020). Impact of Pandemic Covid-19 on Education in India. International Journal of Current Research, 12(7), 12582-12586. https://doi.org/10.24941/ijcr.39209.07.2020

Shaharanee, I. N. M., Jamil, J. M., \& Rodzi, S., S., M. (2020). The Application of Google Classroom as a Tool for Teaching and Learning. Journal of Telecommunication, Electronic and Computer Engineering, 8(10), 5-8.

Yandell, J. (2020). Learning under Lockdown: English teaching in the time of Covid-19. Changing English Studies in Culture and Education, 27(3), 262-269. https://doi.org/10.1080/1358684X.2020.1779029

Heggart, K. R., Yoo, J., \& Heggart, K. (2018). Getting the Most from Google classroom: A pedagogical framework for tertiary educators. Australian Journal of Teacher Education, 43(3), 140- 153. http://ro.ecu.edu.au/ajte/vol43/iss3/9

Azhar, K., A.\& Iqbal, N. (2018). Effectiveness of Google Classroom: Teachers' Perceptions. Prizren Social Science Journal, 2(2), 52-66.

Northey, G., Bucic, T., Chylinski, M., \& Govind, R. (2015). Increasing student engagement using asynchronous learning. Journal of Marketing Education, 37(3), 171-180. https://doi.org/10.1177/02734753 